\title{
On Learning Spaces in Higher Education: Space as an Agent of Change
}

\author{
Pedro Silva \\ Escola Superior de Tecnologias de \\ Castelo Branco, Instituto \\ Politécnico de Castelo Branco, \\ Castelo Branco, Portugal
}

\author{
psilva@ipcb.pt
}

\author{
Luis Borges Gouveia \\ Universidade Fernando \\ Pessoa, \\ Porto, Portugal
}

Imbg@ufp.pt

\begin{abstract}
This paper is the result of a qualitative research conducted between February 2009 and March 2010 among university professors. The selection of university professors was made taking into consideration their experience both in higher education and past innovative initiatives and was conducted to find the best learning spaces' realities and experiences. The followed criteria were being a Higher Education professor, having a considerable experience in higher education (more than 10 years), being involved in research projects in the field of Information Systems, learning spaces, or virtual learning environments and distance education (eLearning), and using Information and Communication Technologies and teaching in an environment where digital technology was explored.

The research was designed to get a model that represents the state of art for the development of the Learning Spaces and proposes a discussion of space's component organization as one of the important factors in its creation. The main ideas and conclusions (resulting from the interviews to the selected Higher Education professors) produced important contributions and confirm the need to make changes in current higher education learning environments.
\end{abstract}

Keywords: Learning Spaces, Learning Environments, Higher Education, Teaching and Learning, Information and Communication Technologies (ICT).

\section{Introduction}

Finding new ideas about space needs, represent a significant opportunity for higher education in order to contribute to make learners and learning more successful (Brown, 2005).

So, the results obtained with this investigation focused primarily on perceptions related to Learn-

Material published as part of this publication, either on-line or in print, is copyrighted by the Informing Science Institute. Permission to make digital or paper copy of part or all of these works for personal or classroom use is granted without fee provided that the copies are not made or distributed for profit or commercial advantage AND that copies 1) bear this notice in full and 2) give the full citation on the first page. It is permissible to abstract these works so long as credit is given. To copy in all other cases or to republish or to post on a server or to redistribute to lists requires specific permission and payment of a fee. Contact Publisher@InformingScience.org to request redistribution permission. ing Environments, the needs of space, the adoption of ICT in learning spaces and the type of spaces using such requirements and its advantages.

The purpose of the perceptions of Learning Environments was to capture a set of personal experiences related to spaces used by teachers, particularly "classroom", collaborative spaces, social spaces and virtual spaces. The main 
contribution of this study was to facilitate the creation of new Learning Environments and make a discussion of space's component organization as one of the important factors in the creation of a learning space. The main ideas and conclusions (resulting from the interviews to the teachers of Higher Education) produced important contributions and confirm the need to make changes.

\section{Data and Research Methods}

All of the interviews in this study were tape-recorded with the professors' permissions, and later transcribed to provide accurate records for analysis. Standard procedures were followed to maintain the confidentiality of the interview data and the anonymity of the teachers. The interviews were structured around a list of topics based on concepts presented in the existing literature, including sharing preferences with regard to the type of information, the person or group with whom the information is being shared, and the purpose behind sharing. The core topics were as shown in Table 1.

Table 1: Core topics of the study

\begin{tabular}{|c|c|c|}
\hline Topics & Objective & Asked Questions \\
\hline $\begin{array}{l}\text { I. PERCEPTIONS } \\
\text { ABOUT LEARNING } \\
\text { SPACES }\end{array}$ & $\begin{array}{l}\text { To capture subjective percep- } \\
\text { tions about learning spaces, } \\
\text { what kind of spaces are known, } \\
\text { and it's importance }\end{array}$ & $\begin{array}{l}\text { Q1 - Let's talk about learning Spaces, } \\
\text { space from classroom, collaborative } \\
\text { space, social space and virtual space. } \\
\text { From your experience as a professor } \\
\text { what is meant by each of these spac- } \\
\text { es? }\end{array}$ \\
\hline $\begin{array}{l}\text { II. PERCEPTION ON } \\
\text { THE NEEDS OF THE } \\
\text { AREA }\end{array}$ & $\begin{array}{l}\text { To capture their experiences } \\
\text { about learning spaces, the needs } \\
\text { and what kind of equipment } \\
\text { should be part of. }\end{array}$ & $\begin{array}{l}\text { Q2 - What do you think about an } \\
\text { ideal learning space? } \\
\text { Q3 - If you were asked to design a } \\
\text { learning space, what aspects do you } \\
\text { find relevant to consider? }\end{array}$ \\
\hline $\begin{array}{l}\text { III. PERCEPTION ON } \\
\text { THE ADOPTION OF ICT } \\
\text { IN LEARNING }\end{array}$ & $\begin{array}{l}\text { To find points of views (needs / } \\
\text { priorities, usefulness, quality } \\
\text { and sustainability) produced by } \\
\text { the use of information and } \\
\text { communication technologies in } \\
\text { learning contexts. }\end{array}$ & $\begin{array}{l}\text { Q4 - In your opinion what is the role } \\
\text { of Information Technologies and } \\
\text { Communication in the quality of } \\
\text { learning and the interacting with the } \\
\text { learning space. }\end{array}$ \\
\hline $\begin{array}{l}\text { VI. PERCEPTIONS } \\
\text { ABOUT THE TYPE OF } \\
\text { SPACE ATTENDED, } \\
\text { THEIR NEEDS AND } \\
\text { ADVANTAGES }\end{array}$ & $\begin{array}{l}\text { To find good practice (or not) of } \\
\text { the use of Space }\end{array}$ & $\begin{array}{l}\text { Q5 - Tell me how you feel about: } \\
\text { What do you enjoy most in this } \\
\text { School? } \\
\text { What do you not enjoy in this School } \\
\text { / learning space? } \\
\text { What do you think about the utiliza- } \\
\text { tion } \\
\text { of space at this school? } \\
\text { What would you like to see changed } \\
\text { in the future? }\end{array}$ \\
\hline
\end{tabular}

The interviews were engaged in a series of decision-making sessions regarding how many professors are need to be interviewed and how to select them for participation in this study. A criterion sampling scheme was used to select professors for the interviews. The followed criteria were: being a Higher Education professor; having experience in higher education, more than 10 years; being involved in research projects in the field of Information Systems, learning spaces, or virtual 
learning environments and distance education (eLearning); using Information and Communication Technologies and teaching in an environment where digital technology was explored in same way.

The interviews were face-to-face. Between the first and second interviews sets, almost three months elapsed. Based on our previous research experience interviewing professors, we felt a second interview set was required to build theory. A strong rapport was necessary to obtain trustworthy data.

The analysis of data was as follows:

First the participants were assigned identification numbers and audio-taped interviews were transcribed verbatim, checked for accuracy, and edited by the first author to ensure that the transcriptions reflected the actual interviews by simultaneously listening to the recordings while reading the transcriptions and making corrections where necessary. These transcriptions were entered into the data management program NVivo 8 after each interview, who provide the tool to support qualitative research based on textual and context analysis as specified by the Grounded Theory methodology.

As a result, data were coded into categories and nodes, and analyzed for themes and repeated patterns, through methods of constant comparison, described by Glaser and Strauss (1967). Categories, concepts, and proposed models were presented to a reference group of teachers for feedback on the process derivation and presentation, rather than content, of the models to see if the methods, concepts, and models presented made sense. From these analysis were derived the framework presented in this study.

\section{Results and Discussion}

In Figure 1 we present the main results of this study.

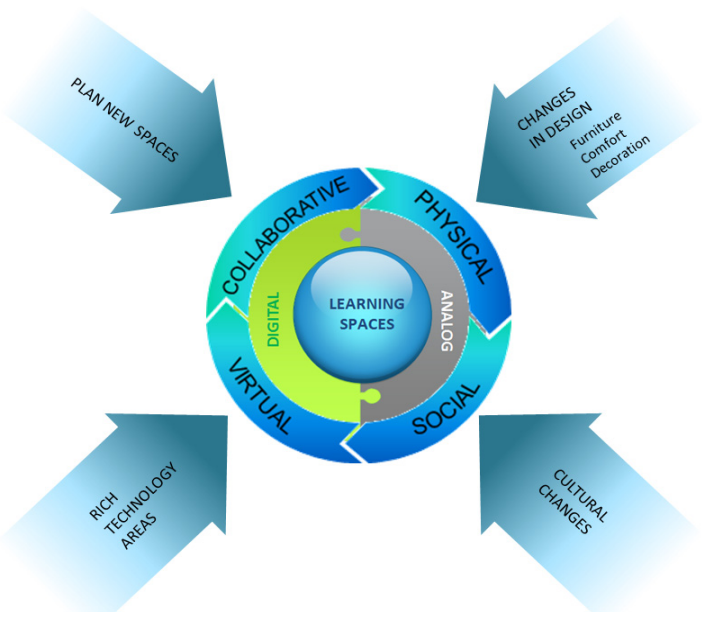

Figure 1: Principal conclusions of this study

This investigation suggests many positive consequences and different points of view on the Best Practices on the use of teaching/learning spaces. To structure the principal findings that have been obtained from qualitative research, we will use three separated dimensions: (i) Perceptions of Learning Environments; (ii) Ideal learning space; (iii) Information and communication technology (ICT) in learning spaces. 


\section{Perceptions of Learning Environments}

- All teachers knew and used the mentioned spaces. The concept of learning spaces was often confused with the classroom.

- The Classroom was recognized by all participants in this study as the most important space and reference in any educational institution. They all share the idea that the classroom's space must change, because of the new teaching methodologies, the introduction of new ICT, and the new students.

- The concept of Collaborative Spaces is not new; most of the teachers consider it very important because "it is impossible to work alone".

Some of the participants recognize that the way students collaborate with each other is important. In the new society's model, known by the network society, collaboration leads and collaborative learning spaces must be a reality.

We all agreed that collaborative spaces must exist with all the needed resources.

- The concept of Social Spaces was the most difficult to identify and characterize. Teachers had some difficulties distinguishing collaborative spaces and social spaces. Virtual Spaces were the most identified and referred. All teachers stated examples from the institutions they belong to. They all used and recommended such spaces. Several examples of Managing Learning Systems applications (LMS) and Virtual Learning Environments (VLE), exploring Open Source or developed by them, are refereed. They all work and provide a range of features, for teachers and students.

One sentiment expressed with displeasure, was the fact that a better integration with the space and the classroom space is possible. "The potential of this is very limited, functioning as a repository of content". These spaces should, besides the educational environment to support the student's learning, also function as a personal tool to prepare classes' supporting material, to perform administrative tasks, to seek information and materials and be used as an interactive communication tool between professors and educational partners.

The main goal relating the space needs was to capture experiences about frequented learning spaces, what kinds of equipment and features should be part of.

We asked respondents to characterize an ideal learning space and to identify aspects they think these spaces must have.

Of all contributions collected that have been sensed as a consensus across all participants, the models and the spaces present in our institutions of higher education do not meet the needs of students and professors.

All participants held that the models and spaces in our Higher Education institutions do not satisfy students and professors' needs.

- The traditional classroom space is too limited, most of the time teachers are in a pulpit where knowledge flews in only one direction. Interaction between the teacher and students is almost impossible;

- This paradigm leads to changes in students and professors attitudes; 
- There was no change in teaching and of course there was no change in the classroom. In my opinion it is essential to start on one side or the other and, if it is possible, on the two.

- It is important to create a psychological comfortable atmosphere between professors and students in order to improve physical comfort;

- Learning in our universities is one of the core activities. Education should be an intense and motivating experience as many others that provide more physical pleasure;

- The space organization and layout must follow that approach. The traditional classroom doesn't reflect the current paradigms. I remember university as being an inhospitable and uncomfortable place. I often felt like running out. Therefore, this concept must change.

- Universities must have well-equipped rooms. Space must have a minimum comfort, and luxury does not mean comfort.

We asked the respondents to characterize the importance of space in teaching and learning activities. All the individuals interviewed characterized space as one of the main factors influencing teaching and learning quality. The way we organize space influences the quality, the way we collaborate, interact and share knowledge.

\section{Ideal Learning Space}

We asked to make a projection of the Ideal Learning Space. Our intent is to understand and characterize technology and the needed equipment to create such space. All participants held that an ideal learning space needs technology, adjustable furniture, different teaching methodologies, perfect environmental conditions and motivation.

All respondents stated that the current Space is very far from the Ideal learning Space. This type of space does not cover both professors and students needs. Respondents held that it is important to create individual spaces for each student, the existence of open spaces, smaller learning spaces, classrooms with mobilization facilities and the creation of "activity islands".

\section{Information and Communication Technology (ICT) in Learning Spaces}

Information and Communication Technologies (ICT) brought to Learning Environments several improvements. We asked respondents what they think about the adoption of technologies in Learning Environments. They all use and consider it essential in the classroom, but they also mentioned several conditions that cause the inappropriate use of technologies. They also held that access, maintenance, management and integration in the classroom are important.

On the other hand, the use of Internet, essential for search, collaboration and communication, also brings some problems. To use ICT in learning spaces we need network and permanent available technological resources that, many universities do not have.

Respondents also reported the insufficient specialized resources (human, materials and network) to support technologies.

Institutions do not project the availability and technologies access to be used by professors and students in learning spaces.

Difficulties related to technology access, maintenance, support and management in higher education institutions lead, despite its presence, to insufficient utilization.

The use of Information and Communication Technologies (ICT) in Learning Environments is limited both as a result of professors' skills and as financial and operational restrictions. Institu- 
tions don't have the necessary conditions so that they can be used as part of the individuals' formative process.

\section{Organization of Learning Environments}

Recognizing the importance of Space in creating high quality Learning Spaces, and considering the weak technology's adoption as the only factor to create these spaces, we present the main reflections from interviews. In figure 1, to ease understanding, we propose a model that presents the principal conclusions of this study. The organization of Learning Space should not be limited only to classroom. It is important to consider all types of spaces (inside and outside the classroom). A new perception of space, where the physical and virtual environments influence each other, may create new forms of socialization, new learning styles and new lifestyles.

Another important related concept is the nature of social learning; this should be represented in both the formal and informal. Culture changes in education require teachers, students and community to realize that learning should not be limited to the school and even less to a limited period of time.

Technology it's an important point in the creation of Learning Environments, but by itself it does not bring significant changes. Changes in design comfort and Decoration and Cultural Change must be part of a Space Learning.

\section{Conclusion}

This study complements and expands the knowledge about space use within higher education Learning Spaces.

We conclude that planning new spaces, changes in design, furniture, decoration and comfort; cultural change, technology-rich areas in Organization Learning Environments are the most relevant factors in the construction and organization of learning spaces as the main categories obtained from the current investigation.

New areas, such as the collaborative learning spaces, should be considered in the organization. The changes in furniture design, comfort and decoration, how the materials are arranged and organized, seem to influence the teaching and learning processes. They are a fundamental part of higher context where human beings can enhance their learning activities.

The cultural change, social spaces and informal learning environments, seem to be a key role to have a good psychological environment and motivate the participation in school activities.

To create high-technology learning, technology-rich spaces, the use of Virtual as an available tool to teaching and learning and its necessary integration with the physical, seem to be essential. The results also show that space has an influence on learning and that the digital and its presence in spaces require new rhythms of Teaching and Learning.

\section{References}

Brown, M. (2005). Learning spaces. In D. G. Oblinger \& J. L. Oblinger (Eds.), Educating the net generation. Boulder, Colo.: EDUCAUSE [e-book].

Glaser, B., \& Strauss, A. (1967). The discovery of grounded theory: Strategies for qualitative research. New York: Aldine Publishing Company.

Oblinger, D. G. (Ed.) (2006). Learning spaces. EDUCAUSE. ISBN 0-9672853-7-2 [e-book].

Silva, P., \& Gouveia, L. B. (2008). ED-MEDIA 2008, Learning Space, June 30 -July 4. ISBN : 1-880094$65-7$ 
Silva, P., \& Gouveia, L. B. (2010). INTERTECH'2010, A Geração Digital no Novo Mundo Empresarial. Março 07-10: Ilhéus, Brasil; ISBN : 978858912075-3

Strauss, A., \& Corbin, J. (1990). Basics of qualitative research: Grounded theory procedures and techniques. Sage Publications.

Strauss, A., \& Corbin, J. (1998). Grounded theory methodology: An overview. In N. K. Denzin \& Y. S. Lincoln (Eds.), Strategies of qualitative inquiry. Sage Publications.

\section{Biographies}

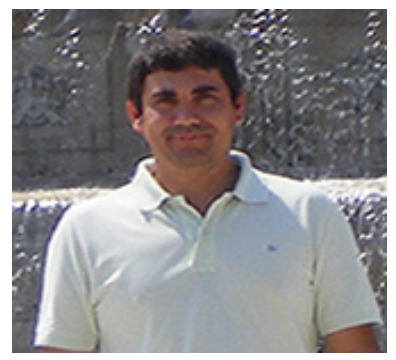

Pedro Silva is a teacher at Polytechnic Institute of Castelo Branco. He is a Phd student at the University of Fernando Pessoa, Porto. He holds a Master degree in Organization and Information Systems (University of Evora, 2005) and a degree on Computer Science (University of Lusófona, 1999). His interests are in the application of computer technologies in education, in particular, the use digital environments and impact space in higher education.

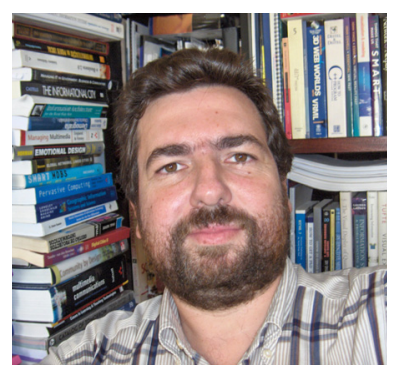

Luis Borges Gouveia is an Associate Professor at University Fernando Pessoa. He holds a PhD in Computer Science (University of Lancaster, 2002) and a Masters degree in Electronic and Computers Engineering (University of Oporto, 1995). His interests are within the impact of information society and digital use both in education and business.

Luis has a Web homepage at http://homepage.ufp.pt/ lmbg 